\title{
La Casa de Esperanza: The House that Multicultural Education Built ${ }^{1}$
}

\author{
Francisco Rios \\ University of Wyoming
}

U. S. A.

Using a house (la casa) as a metaphor, this manuscript attempts to provide a broad overview of the field of multicultural education as an academic discipline. It includes viewing multicultural education from a macrolevel perspective (el barrio), describing many paths multicultural educators have taken (los calles), and reading the stories of oppression and resistance which they face (los paredes). It details the icons in the field (la entrada), the people with whom we work everyday (la sala), the places for networking and academic engagement (el patio), the myths and stereotypes as well as our responses to these about multicultural education (la cocina), and the tough issues we have yet to address fully (el ropero). It ends with a description of promising practices and a long-term vision (including the DREAM Act) for multicultural education (el techo). Chicano Art is used throughout.

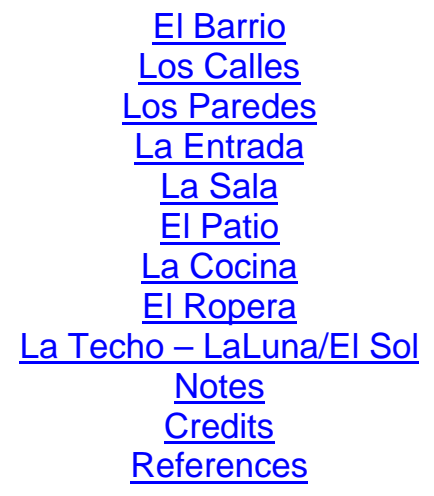

For this inaugural issue of the International Journal of Multicultural Education, I was invited to offer a perspective on where we are in the field of multicultural education. As an individual scholar who has pursued research in multicultural education as an academic discipline and as a member of several organizations committed to supporting and advancing the multicultural work of the collective, I am honored to provide one such perspective.

I have titled this essay "La Casa de Esperanza: The House that Multicultural Education Built." La Casa de Esperanza, the house of hope, is exactly what I see that centers our work in multicultural education: a house where we work to counter hate-mongering and to nurture hope-mongering as described in Herbert Kohl's book, I Won't Learn from You (1994). Multicultural education is an academic discipline where we are guided by, and foster, many 
kinds of hope for schools as they might be, communities as they might be, and nations as they might be.

For me, La Casa de Esperanza was also the name of a community-based organization in Wisconsin where I was nurtured and mentored, and it was a place where I had my first real opportunity to nurture and mentor others. It was the home of one of my mentors, Dr. Walter Sava, who taught me about the importance of serving by centering one's work in the needs of the community and continually pursuing creative action. It was the home of the summer youth education and recreation program that I directed for two summers, during which over 100 Latino youth and 10 Latino counselors taught me much about the importance of joy and learning and kept both present. It was home to the bilingual community newspaper, El Águila, for which I served as Editor, where I learned the importance of news as a story by using the newspaper to tell the story we wanted to tell in the way we wanted to tell it.

La Casa de Esperanza, the house of hope. I also want to use la casa, the house, as a metaphor and an organizing device to share my perspectives on where we are, from the vantage point of la casita mía, my house, in the field of multicultural education. In doing so, I want to describe both what issues still challenge us and what dreams and goals still sustain us from the vantage point of my house located in the United States.

I assert that a house is a productive organizing device since it shows wholeness, connectedness, and the roles of different parts. Likewise, I acknowledge that each of you, dear readers, has your own house that offers a different vantage point. As your house is differently framed and laid out, the issues, challenges, dreams, and goals you see may be different from others. Recognition of multiple perspectives, after all, is one important goal of an education that is multicultural. Thus I encourage you to think about how you would describe the house that serves as your multicultural home, especially for those of you outside United States. Notwithstanding our individual houses, we must also acknowledge that we are neighbors, friends, and family and that we live together in the same barrio, the same ghetto, the same reservation, or the same city or town.

I'm borrowing this notion of casa or house as a metaphor from a Chicano art text titled Chicano Art: Inside-Outside the Master's House by Alicia Gaspar de Alba (1997). As such, I will use text to introduce you to several outstanding works of Chicano art $^{2}$ as well since art in education is viewed by Latinos as a cultural and community asset, one which might help students to learn, validate their culture, promote community-school integration, and encourage respect across cultures (National Latino/a Education Research Agenda Project, 2003). In sum, what I'm offering here is a distinctly Latino-centric perspective into nuestra casa de educación multicultural. 


\section{El Barrio}

I want to begin with a macro perspective. To do this, we need to think about the place where our casa rests-el Barrio. Thinking of the barrio allows us to think of the larger context of our work in multicultural education. Like many barrios around the United States, ours is also a barrio under attack. Our barrio is part of a larger nation-state often hostile to our work.

Consider the standardization of a Eurocentric curriculum and its manifestation in scripted instruction and standardized assessments to codify the western canon and to compel teachers to stick to the script-at a time that our schools are more diverse than ever. Consider the most recent desegregation decisions by the Supreme Court, which ruled against initiatives leading to greater integration in Louisville and Seattle. These court decisions come on the heels of other court cases that are not only distinctly anti-integration but downright hostile to diversity - at a time when schools,

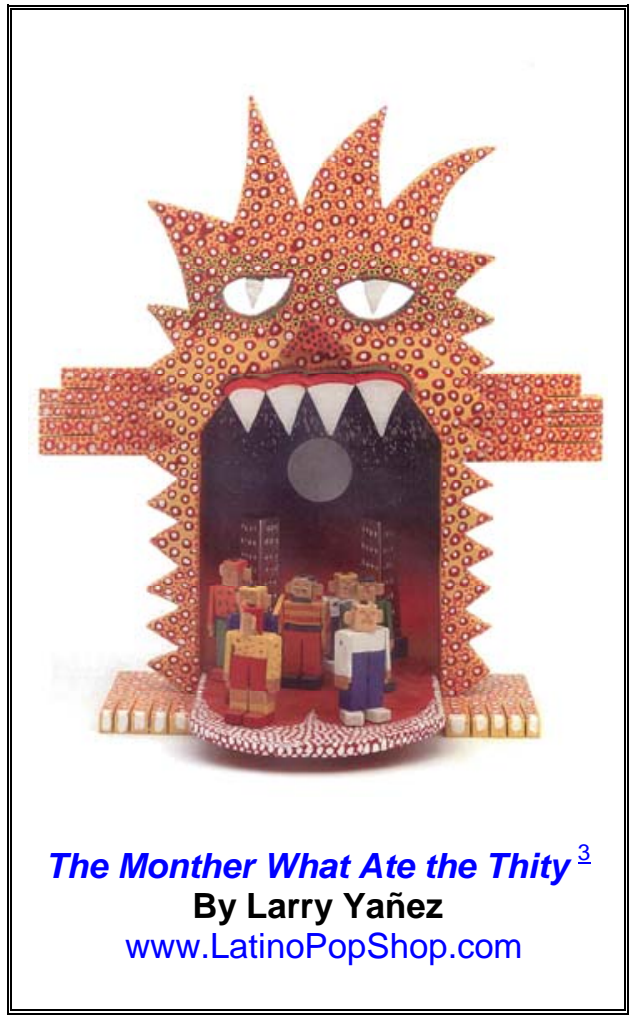
communities, and the nation have become nearly as segregated as before the Brown vs. Board of Education case. Consider the anti-bilingual education movement, successful in dismantling bilingual education in Arizona, California, and Massachusetts-at a time when English language learners are the fastgrowing student population and the need for people who have multiple language abilities is also increasing. Consider the anti-immigrant hysteria being conjured up. This has led to the building of walls and the militarization of our southern border, as well as the denial of vital human services to immigrants including medical care and housing - in a nation where the majority of people can trace their own roots to immigration and at a time when companies and businesses depend so greatly on their labor, a labor from which we all benefit.

Indeed, we all recognize that education is a political activity. The Brazilian educator and philosopher/activist Paolo Freire (1973) described it this way:

There is no such thing as a neutral educational process. Education either functions as an instrument which is used to facilitate the integration of the younger generation into the logic of the present system and bring about conformity to it or it becomes the "practice 
of freedom"- the means by which men and women deal critically and creatively with reality and discover how to participate in the transformation of their world. (p. 15)

Not all outside our barrio is hostile. We can look, and we have looked, to other disciplines, to other barrios, to identify work that is productive and helpful for our own academic home. Consider, for example, how work in law around critical legal studies spurred the development of critical race theory (Delgado \& Stefanic, 2000) that has been such a productive addition to our scholarly work in multicultural education. Consider the work being done by the Maori, especially by Linda Tuhiwai Smith (1999), around decolonizing research methodologies that have spurred others to consider how colonization has happened and decolonization can occur in our communities. While social movements have ebbed and flowed in the United States over the past 10 years, they are a vibrant part of the political activism in other parts of the world, spurred to contest neoliberalism, militarization, and neo-colonialism.

The macro-view, then, of the barrio shows competing and contesting political ideologies that significantly influence our barrio, multicultural education.

Within our barrio, though, are the places we call home: A place in which we live and work to carve a vision of who we are and what we believe. These homes are places where we can ask difficult questions to each other; being in the same barrio, after all, does not imply that there is not room for loving criticism.

\section{Los Calles}

To navigate the barrio, we enter onto its streets. Los Calles, the streets, represent for me the paths we take. As we look at the network of streets and alleys which tie our barrio together, we recognize that there are many different roads, many different paths, and many different markers along our way. Yet, they are all part of the same barrio, the same community.

Mis calles, the streets I have followed, have taken me from Denver, to Wisconsin, to California, and now to Wyoming - a wild, windswept, and conservative place which no doubt presents difficult issues and challenges for multicultural educators. Those Wyoming streets have allowed me to follow two new paths.

One path keeps me connected with Native American students and community activists and schools on the Wind River in central Wyoming. As I walk on this path, I'm reminded by the signs along the way to slow myself down, to look at school, education, and life more holistically because of the natural connectedness of all things, and to appreciate the gift l've been given to take a role as an observer and learner in their cultural pathways and as an assistant in 
their drive for self-determination. Another path takes me to Jackson, at the foothills to the Tetons, where a large number of immigrant students and their parents live and work. As I walk on this path, I'm reminded by the signs along the way to admire the journey stories people tell, to hold up the strength of a community's resilience despite frequent attacks, and to serve as a resource for those community activists and those school professionals who really want to make a difference in the lives of the young people with whom they work.

We learn from the paths that we take that are near our homes. I encourage you to consider what you have learned along the paths of multicultural education that you have taken.

\section{Los Paredes}

Parking on the street, in front of the house, one sees the first part of the home- -the walls, los paredes. Like the murals which can be found on walls within almost every barrio, we need to read the walls which surround us. The walls tell us the many stories of oppression and resistance. In reading the walls, we see plenty of examples of oppression since the macro-cultural context, the larger oppressions which I noted earlier, sets the stage for the more local oppression each of us faces within our own barrio, sometimes even within our own home. For me, then, even within our homes in academic institutions, the places of supposed enlightenment and learning, we can still experience oppression.

Consider just these three examples:

- A co-worker, in a search and screen committee that I was part of, said we didn't have to hire any candidates from diverse backgrounds since the last candidate we hired was from a diverse background and wasn't the most qualified. I was that last candidate.

- A phone call that I received from an administrator the very next morning after Proposition 209-the Civil Rights Initiative which sought to end preferences based on race, ethnicity, and sex (including affirmative action) - passed in California, inquiring whether a minority teacher recruitment program which I was chairing "discriminated" against White students. He had not called the athletics department, the scholarship offices, or the alumni association to inquire if they gave preferences in a way that discriminated against people of color. He chose to call me.

- An administrator one day was discussing the importance of supporting bilingual education and defeating Proposition 227, which sought to abolish bilingual education in California. Within a week of its passage, he invited me to work with a school district to help them to do the 
"English-only" program better. What did he really believe about bilingual education?

These local oppressions are small. I imagine every reader has her or his own examples. They make up the day-to-day indignities that are sometimes thrust upon us and to which we must respond. Indeed these little oppressions ARE big. Sherman Alexie in The Lone Ranger and Tonto Fistfight in Heaven (1993) described it best:

Still, Indians have a way of surviving. But it's almost like Indians can easily survive the big stuff. Mass murder, loss of language, and land rights. It's the small things that hurt the most. The white waitress who wouldn't take an order, Tonto, the Washington Redskins. (p. 49)

Fortunately, resistance is part of the stories these walls tell as well. Daniel Solórzano and Dolores Delgado Bernal (2001), in their article "Examining Transformational Resistance through a Critical Race and LatCrit Theory Framework," tell us that sometimes our very presence is an act of resistance. Sometimes our act of resistance is to persist, knowing that our own advance and upward movement will allow us to make even greater changes in the service of social justice. Sometimes our acts of resistance have been, indeed must be, explicit, confrontational, and non-negotiable. Making my presence known and legitimated, garnering a grant to allow me to take action, and leaving a job when the full weight of social injustice became too much and other acts of resistance became too futile-these are the stories of resistance my walls tell.

\section{La Entrada}

As we open the front door, as we first enter a home, la entrada, the entry, is the first thing we see. In the entryway, we position the things we most want others to see: pictures of people who are important to us, objects we are most proud of, and the icons we hold most high. In the house that multicultural education built, these are the people, organizations, projects, conceptions, and ideologies whose contributions we stand upon. We need to constantly acknowledge their work and their support.

For me, in my house, it is people's academic contributions, like that of Christine Sleeter and Carl Grant (2006), Sonia Nieto (2004), and Geneva Gay (2000). But it is also Rethinking Schools (www.rethinkingschools.org) and the Southern Poverty Law Center (www.splcenter.org). It is the collaborative work being done by the ethnic studies program at Tucson Unified School District; the minority teacher recruitment programs in Kentucky, South Carolina, and Utah; and the urban teacher education programs like Project $X$ at UCLA. These are people, projects, and places where a difference is being made. 
These are the icons I most hold up and want others to see, and these are the things I want others to know about when they first enter my multicultural house.

\section{La Sala}

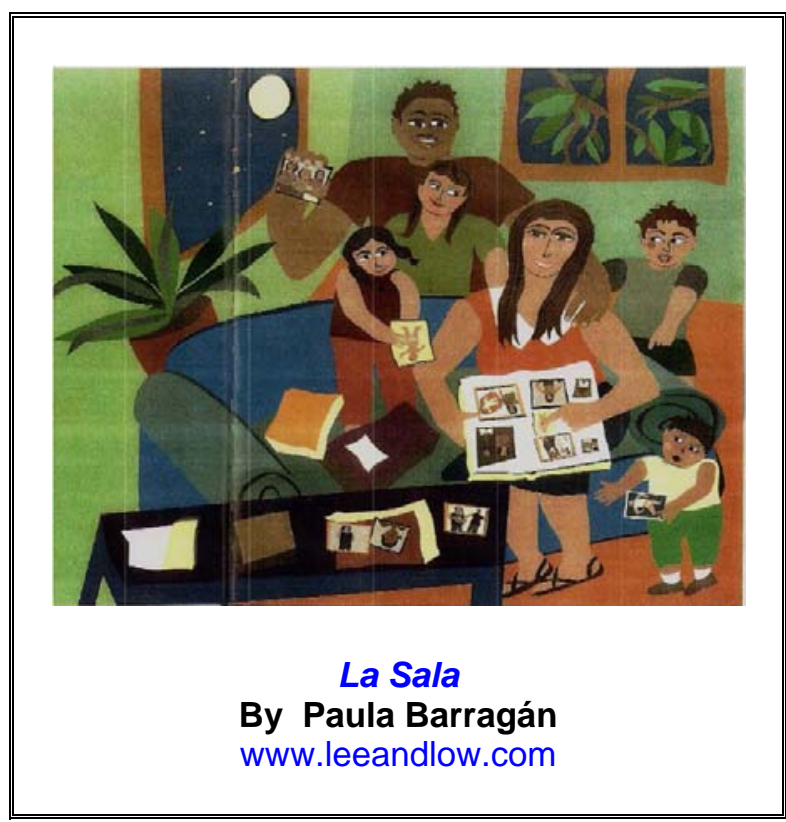

the American G. I. Forum. Eventually he became president of a national labor organization and she an active member of the Democratic Party. Tía Ramona ran for Denver City Council and won, and her time on the council included several years, during which she chaired the city council, which elevated her as the second most powerful politician in Denver City politics.

For me, this includes members of my own college and university. It includes colleagues like Leticia who reminds me to see the best in all students, Allen who shows me the difference White allies can make, John who teaches me about the importance of pursuing passion, and Rosie and Angela who live the various forms that personal and professional resistance and resilience can take. It includes Iva and Mike on the Wind River, a rock of cultural strength for their community, and it includes Gina and Carmina in Jackson, pursing advocacy and social service with passion, pride, and purpose.

I urge readers to think about those people most near you, the people in your living room, and the difference they make in the lives of others. 


\section{El Patio}

As we move beyond the living room, we enter into the patio, el patio, the gathering place for special occasions and the gathering place for the larger family. Like all families, there are certain things we do together as a family, almost as a ritual.

The National Association for Multicultural Education provides one such patio for me. It is where our family comes together, like for a holiday when we gather not just our immediate family, but also our large extended family. We come together.

Like on those holiday get-togethers, we gather to talk in small private moments as well as in large public moments. We gather together to meet, to greet, and, yes, even to eat. But we also gather together to listen, to share, and to think. We gather for both spiritual and academic nourishment. We gather for camaraderie.

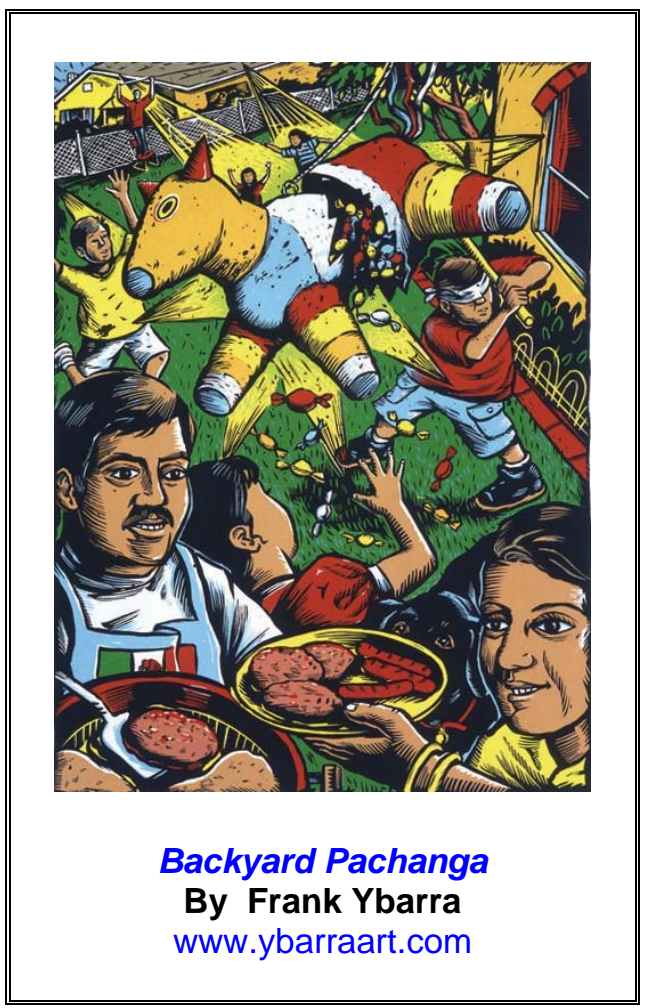

While it is true that any family is made up of a collection of distinct individuals and personalities, who come from different places, we also share a special something nurtured on the paths we continue to take as multicultural educators. Perhaps it can best be described as a shared value system:

- Affirm diversity and identity;

- Build caring communities;

- Value students' cultural assets;

- Promote a culturally and linguistically responsive pedagogy;

- Adopt a holistic view; and

- Pursue social justice by opposing oppression and promoting resistance.

As Freire (1998) reminds, do all this with love: "It is impossible to teach without the courage to love, without the courage to try a thousand times before giving in. In short it is impossible to teach without a forged, invented, and wellthought-out capacity to love" (p. 3). 


\section{La Cocina}

The next room in our casa is la cocina, the kitchen, the place where things are cooked up. These include those myths and misconceptions that are being cooked up about us as individuals and about our organizations, which push up against multiculturalists, multicultural education, and multiculturalism.

Consider all those stereotypes, myths, and misconceptions that we must address and respond to head on: the myth of meritocracy, the myth of AngloWhite superiority, and the myth of racism as a thing of the past. We must also counter beliefs that multicultural education is an anti-democratic movement and that its implementation in school is centered on helping students "feel good" so therefore it cannot be academically rigorous.

We multicultural educators can cook things up, too, when we offer our own creative responses. Sometimes the response comes by way of an appetizer, a quick-witted response. One White student was complaining that talking about race issues was like "walking on egg shells." An African American student responded, "Oh, yeah, well try being the egg."

Sometimes the response is more substantial like a main course, prepared from the ingredients already existing in the kitchen. Such is how I would characterize Christine Bennett's (2001) review of educational research, titled "Genres of Research in Multicultural Education." Bennett lists important assumptions which stem from the research in the field, including:

- Knowledge is constructed and contested;

- A Eurocentric curriculum in the United States is a tool of cultural racism;

- Teachers' and students' cultural locations and sense of ethnic identity influence teaching and learning; and

- Social change, necessary to bring about equity in education, is both possible and consistent with basic democratic values and the American creed.

In my home, we sometimes enjoy a dessert, something deliciously sweet. In Wyoming, the state legislature provided millions of dollars in state match, dollar for dollar, for any contributions to the University's endowment account. Soon after the university received a one-million-dollar donation for diversity and social justice-related initiatives, the conservative state legislature matched it by another one million dollars. This funding has helped to institutionalize three important diversity-related initiatives on the campus: the Shepard Symposium for Social Justice, the MLK Days of Dialogue, and the Social Justice Research Center. We can never get enough dessert, que no? 


\section{El Ropero}

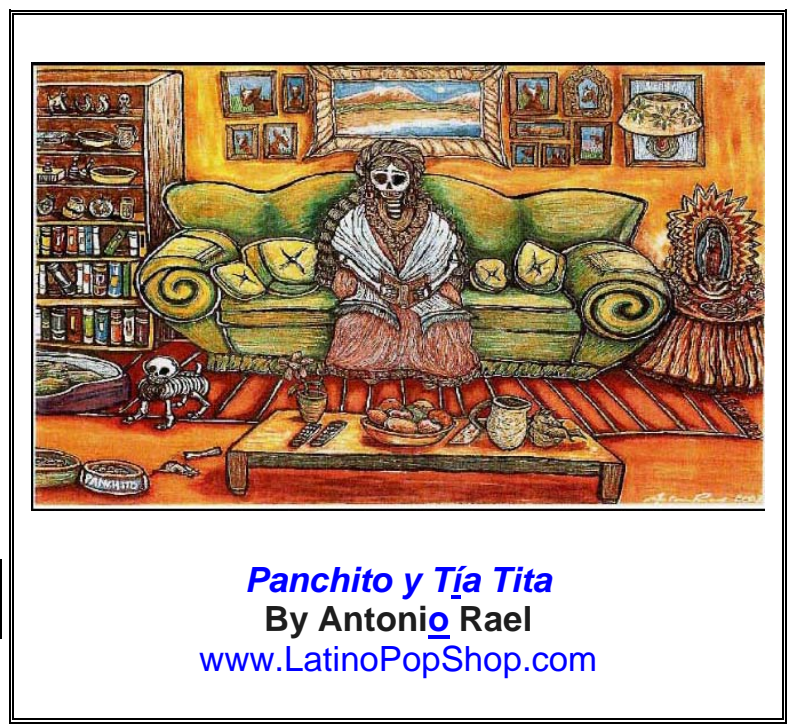

All houses, including your house and mine, have a closet, el ropero, where we try to keep things hidden. These are the places where our proverbial skeletons rest. El ropero is important because it represents for us the challenges we still have yet to confront. For each of us, what we see hidden in el ropero is different.

In the ropero that I see, we have these three skeletons. Seeing them spurs me to ask these questions. First, how are we doing when we think about and respond to

gender, sex, and sexual orientation? Do women, who are and have been the backbone of this academic discipline, get the respect and accolades so due? To what degree do we combat homophobia when homophobic tendencies may be evident even in our own home? Second, have we moved to thinking about and responding to diversity as not exclusively a race issue, but one that includes issues of immigration, disability, language, class, and importantly their intersections? Third, how can we achieve social change via activism when many of us would rather choose safety over risk, when many of us would rather choose comfort over confrontation, and when many of us teach but do not model education that is "multicultural and social reconstructionist" (Sleeter \& Grant, 2006)?

These are skeletons that may have been in our closet for some time. These questions also lead me to ask other questions: For how long do we keep those skeletons in our closet? At what cost do we pay for their presence, personally and organizationally? How and when will we address them in a constructive and productive way?

The closet, el ropero, is part of both my and your house.

\section{El Techo -- La Luna/EI Sol}

I want us to take time to go to the roof, el techo, the last place on the visit to my house. It is from there that we see el sol, the sun, which shines brightly in our lives, which warms us, and which provides light that guides us. 
A few bright spots that warm me can be found in the works done on Latino cultural capital, especially the works of Tara Yosso (2006) and Maria Fránquiz and Maria del Carmen Salazar (2004), which show how Latino cultural capital is an important asset in serving education. The sun shines brightly on the work of some young urban scholars, most notably Jeff Duncan Andrade (2004) as well as Julio Cammarota and Michelle Fine (2007), who are teaching young people participatory action research strategies so that they can tell the stories of their community's struggles with oppression as well as their community's effort at resilience, resistance, and retelling. I am warmed by the work by Dolores Delgado Bernal and her colleagues (Delgado Bernal \& Villalpando, 2002; Solórzano \& Delgado Bernal, 2001) who are using counter-story telling, within a Latino Critical Race theory, in an attempt to challenge and critique the master narrative. I find the light in one of the most recent work done at the University of Washington's Center for Multicultural Education, titled "Democracy and Diversity," by Banks, McGee Banks, Cortés, Hahn, Merryfield, Moodley, MurphyShigematsu, Osler, Park, and Parker (2005). It ties the affirmation of diversity to the larger democratic project. I wonder if linking diversity with democracy might help us to advance the perception and implementation of multicultural education.

From the rooftop, at dusk, in the evening, or when we are weary from the day, we see la luna, the moon. La luna helps us to think about those things far away, the dreams that guide, and the future that begins even before the dawn.

And I think about the hopes I have for my own children, the hopes I have for my students as they move on to become teachers, the hopes I have for the nation to one day to live out its own creed for equality and justice for all, not just for the privileged few. Viewing la luna reminds me that we must never stop hoping, dreaming, and wishing for a brighter tomorrow.

One dream that I urge us all to push for is The Dream Act. The Dream Act is federal legislation that would allow the children who attend K-12 school and graduate from high school here to be considered residents for purposes of higher education, although their parents are here without documentation, and to become eligible for state and federal assistance and in-state tuition breaks at our nation's colleges and universities. I hope this is one dream, The Dream Act, which we can all stand behind individually, collectively, and organizationally.

I close this essay with a spiritual ${ }^{4}$ offering. It reminds us that we must get outside of our homes and find those places in our neighborhoods where we gather as a community, such as a bodega, a store, where we come to replenish our stock of the cultural necessities that will sustain us. We can find a sense of home even in the bodega. The poem is from Martín Espada's (1994) book, Trumpets from the Island of Their Eviction, and is entitled, "Tony Went to the Bodega but He Didn't Buy Anything." 
Tony's father left the family

And the Long Island city projects, Leaving a mongrel-skinny puertorriqueno boy

Nine years old

Who had to find work.

Makengo the Cuban

Let him work at the Bodega.

In grocery aisles

He learned the steps of the dry-mop mambo,

Banging the cash register

Like piano percussion

In the spotlight of Machito's orchestra,

Polite with the abuelas who bought on credit, Practicing the grin on customers He'd seen Makengo grin

With his bad yellow teeth.

Tony left the projects too, With a scholarship for law school.

But he cursed the cold primavera

In Boston;

The cooking of his neighbors

Left no smell in the hallway,

And no one spoke Spanish

(not even the radio).

So Tony walked without a map

Through the city,

A landscape of hostile condominiums

And the darkness of white faces,

Sidewalk-searcher lost

Till he discovered the projects.

Tony went to the bodega

But he didn't buy anything:

He sat by the doorway satisfied

To watch la gente (people

Island-brown as him)

Crowd in and out,

Hablando espanol,

Thought: this is beautiful,

And grinned

His bodega grin.

This is a rice and beans

Success story: 
Today Tony lives on Tremont Street, Above the bodega.

\section{Notes}

1. This essay is based on a keynote address that I delivered on November 2, 2007 at the National Association for Multicultural Education Annual Meeting held in Baltimore, Maryland.

2. In the presentation, I used art work from a variety of Chicano artists. I am able to use a few of these art images herein with permission by artists or publishers. See the credits below.

3. The title is as appeared in the original publication.

4. "Spiritual" is understood by advocates of holistic education as something that brings wisdom, beauty, compassion, and service.

\section{Credits}

1. The painting, "The Monther What Ate the Thity," from Chicano Art for Our Millennium (Erickson et al., 2004) is reprinted with permission by the artist Larry Yañez.

2. The illustration, "La Sala," from Poems to Dream Together (Poemas Para Soñar Juntos), Illustrations copyright ( 2005 by Paula Barragán, is reprinted with permission arranged with Lee \& Low Books Inc., New York, NY 10016.

3. The painting, "Backyard Pachanga," from Chicano Art for Our Millennium (Erickson et al., 2004) is reprinted with permission by the artist Frank Ybarra.

4. The painting, "Panchito y Tía Tita," from Chicano Art for Our Millennium (Erickson et al., 2004) is printed with permission by the artist Antonio Rael.

5. The poem, "Tony Went to the Bodega but He Didn't Buy Anything," is reprinted with the author's permission. Visit the poet's website (www.martinespada.net/) for more information.

\section{References}

Alexie, S. (1993). The lone ranger and Tonto fistfight in heaven. New York: Harper Perennial. 
Banks, J. A., et al. (2005). Democracy and diversity. Seattle, WA: Center for Multicultural Education, University of Washington.

Bennett, C. (2001). Genres of research in multicultural education. Review of Educational Research, 71(2), 171-217.

Cammarota, J., \& Fine, M. (2007). Revolutionizing education: Youth participatory action research. New York: Routledge.

Delgado, R., \& Stefanic, J. (2000). Introduction. In R. Delgado \& J. Stefanic (Eds.), Critical race theory: The cutting edge ( $2^{\text {nd }}$ ed., pp. xv-xix). Philadelphia: Temple University Press.

Delgado Bernal, D., \& Villalpando, O. (2002). An apartheid of knowledge in the academy: The struggle over "legitimate" knowledge for faculty of color. Equity and Excellence in Education, 35(2), 169-180.

Duncan Andrade, J. (2004). Your best friend or your worst enemy: Youth popular culture, pedagogy and curriculum. The Review of Education, Pedagogy and Popular Culture, 26, 313-337.

Erickson, M., Villeneuve, P., Keller G. D., \& others (2004). Chicano art for our millennium: Collected works from the Arizona State University community. Tempe, AZ: Bilingual Review Press.

Espada, M. (1994). Trumpets from the islands of their eviction. Tempe, AZ: Bilingual Review Press.

Fránquiz, M. E., \& del Carmen Salazar, M. (2004). The transformative potential of a humanizing pedagogy: Addressing the diverse needs of Chicano/Mexicano students. High School Journal, 87(4), 36-53.

Freire, P. (1973). Pedagogy of the oppressed. New York: Seabury Press.

Freire, P. (1998). Teachers as cultural workers: Letters to those who dare to teach. Boulder, CO: Westview.

Gaspar de Alba, A. (1997). Chicano art inside/outside the master's house. Austin, TX: University of Texas Press.

Gay, G. (2000). Culturally responsive pedagogy: Theory, research and practice. New York: Teachers' College Press.

Kohl, H. R (1994). "I won't learn from you" and other thoughts on creative maladjustment. New York: The New Press. 
National Latino/a Education Research Agenda Project. (2003). Education research framework and agenda. In P. Pedrazza and M. Rivera (Eds.), Latino education: An agenda for community action research (pp. 471528). Mahwah, NJ: Lawrence Erlbaum.

Nieto, S. (2004). Affirming diversity: The sociopolitical context of multicultural education. White Plains, NY: Longman.

Sleeter, C. E., \& Grant, C. A. (2006). Making choices for multicultural education $\left(5^{\text {th }}\right.$ Ed.). New York: Wiley.

Solórzano, D. G., \& Delgado Bernal, D. (2001). Examining transformational resistance through a Critical Race and LatCrit theory framework: Chicana and Chicano students in an urban context. Urban Education, 36(3), 308342.

Tuhiwai Smith, L. (1999). Decolonizing methodologies: Research and Indigenous people. London: Zed Books.

Yosso, T. (2006). Critical race counterstories along the Chicana/Chicano educational pipeline. New York: Routledge. 